\title{
Aspirations of Scheduled Caste Students in Secondary Education- A Sociological Study
}

\author{
N. Doddasiddaiah ${ }^{1,}$ Dr. S.L. Hiremath ${ }^{2,}$ Dr. C. Somashekher ${ }^{3}$ \\ ${ }^{1}$ Research Scholar, Department of Sociology, Gulbarga University, Gulbarga-585105 \\ ${ }^{2}$ Professor, Department of Sociology, Gulbarga University, Gulbarga-585105 \\ ${ }^{3}$ Professor, Department of Sociology, Bangalore University, Bangalore-560056
}

\begin{abstract}
Education is a real weapon to lead a life in this challenging and competitive society. Every human have his own aspirations in his life which is basically fulfilled by the education. The new sectors and upcoming skilled based jobs have been impacting on the educational system. This paper attempts to study the aspirations of the scheduled caste students studying in the secondary education. This paper is based on both primary and secondary data; Emphasis is focused here on Mysore city. There are 154 high schools / secondary schools running in and around Mysore consisting of 35, 324 students studying in viii, ix \& $x$ standards.. Out of which nearly 3000 students belong to scheduled caste category. Simple random sampling method is used for the present study.
\end{abstract}

Keywords: Aspirations, Career, gender, Secondary Education, Scheduled caste,

\section{Introduction}

It is widely accepted that the process of education begins right from the birth and continues throughout life. Some believe that education begins even earlier than this, as evidenced by some parents' playing music or reading to the baby in the womb in the hope it will influence the child's development.The word 'education' is often used to refer solely to formal education. However, it covers a range of experiences, from formal learning to the building of understanding through day to day experiences. Ultimately, all that we experience serves as a form of education.Individuals can receive informal education from a variety of sources like family members and society that have a strong influence on the informal education of the individual.The term "education" is derived from the Latin word educare meaning "leading out" or "leading forth". This reveals one of the theories behind the function of education- of developing innate abilities and expanding horizons.

Formal education occurs when society or a group or an individual sets up a curriculum to educate people, usually the young. Thus it becomesmore systematic and thorough. Formal education systems can be used to promote ideals or values as well as knowledge and this can sometimes lead to abuse of the system.Lifelong or adult education has become widespread in many countries. However, 'education' is still seen by many as something aimed at children, and adult education is often branded as 'adult learning' or 'lifelong learning'. Adult education takes on many forms from formal class-based learning to self-directed learning. Lending libraries provide inexpensive informal access to books and other self-instructional materials. Many students have also taken advantage of rise in computer ownership and internet access to their further informal education.

\section{The Concept of Secondary Education}

In India secondary education has been traditionally considered a half-way house between elementary education and higher education. In our observation with the necessities of higher education and the paucities of elementary education, we often underestimate the crucial character of secondary education. At present, secondary education is, perhaps, the weakest link in our educational set up. The importance of this sector is that it is the earliest stage which brings the child in touch with the world of work. It also provides the foundation for the really nation-building education in the sense that it helps to develop the highest potential, aptitudes, interests and qualities of children to enable them to take an active part in nation's developmental activities. However, the products of secondary education today are mostly unemployable and unfit to pursue higher studies. The terminal character of secondary education has eroded. Matriculation and S.S.L.C. holders are left high and dry without any legitimate avenues for further progress. Efforts have been made by Mudaliar Commission (1952) to revamp the secondary school system though without much success. The Education commission (1964-66) made several recommendations to improve the quality, content and methodology of secondary education. The National Policy on Education (1968) pleaded for extended secondary education facilities to the areas and classes which had been denied these in the past. The policy statement focused on educational opportunity at the secondary transformation. With this aim attempts have been made to relate education to work and employment by 
introducing socially useful productive work (SUPW) and vocational and technical education as components of secondary education.

\section{Review of Literature}

Chitnis(1993) in her study 'Education of SC's" found that SC's enrolled at schools and colleges come from privileged families, namely, literate homes. But she suggests "it would be useful to examine whether the SC students are economically well off as well". Chitin says that special programmes for the educational development of SC's are giving rise to new inequalities within their castes. She also reveals that SC females who have access to higher education come from privileged families compared to their SC male, counterparts.

Singh (1984) conducted a study of creativity in relation to adjustment, frustration and level of aspiration. The random sampling procedure was used to select 600 male students of classes IX and X from literacy and scientific groups of the secondary schools of Agra city. The major findings were: 1. the high and the low creative students were found to be differ significantly in their total emotional and educational adjustments at 0.05 levels. But they were not found to be differing significantly in their social adjustment. 2 . The role of adjustment, aggression and the level of aspiration were positive in nature but they are in numerically dissimilar.

Das (1982) conducted research some behavioural on problems of the secondary school students of the district of Burdwan and their causes. Eighteen schools were taken from which 130 students of the age group 13 to 15 were selected for study. The distributions include urban fifty-four, industrial forty-two and rural thirtyfour. A matched group of children with the same proportion was selected from non-problem students by randomization. Some of the findings were: 1 . frustration of recognition expectation and feelings of insecurity and inferiority were powerful determinants of behavioural problems. 2. The gap between aspiration and actualization was also found to be one of the causative factors for behavioural problems.

\section{Methodology}

The study was undertaken to analyze the attributions of Scheduled Caste students in Mysore city. Primary and secondary data have been used to construct the objectives of the study. The macro aspects of the study is based on the published and unpublished works on the subject etc. absolutely in the study, books, journals and bulletins are measured to collect data. The primary data was collected by administering the structured questionnaire and interview-schedule in secondary schools. 300scheduled caste students were chosen on random sampling method. The sample statistical tools like percentages and chi-square tests were used to analyze the data.

\section{Objective of the Study}

In view of the above background the present study intends to address the main objective of the present paper that is to identify the aspirations of the scheduled caste students studying in secondary education in Mysore city of Karnataka state.

\section{Results and Discussions}

Each and every individual will have his/her own aspirations in their life. Aspirations are nothing but someone's desire to become or achieve a position in the society. All desires will not become aspirations. When an individual puts his/her efforts towards that desire and chanalize, the desire professionally that desire crystalize after achieving particular efforts could be considered as aspirations.

Fig 1.1: Occupational Aspirations

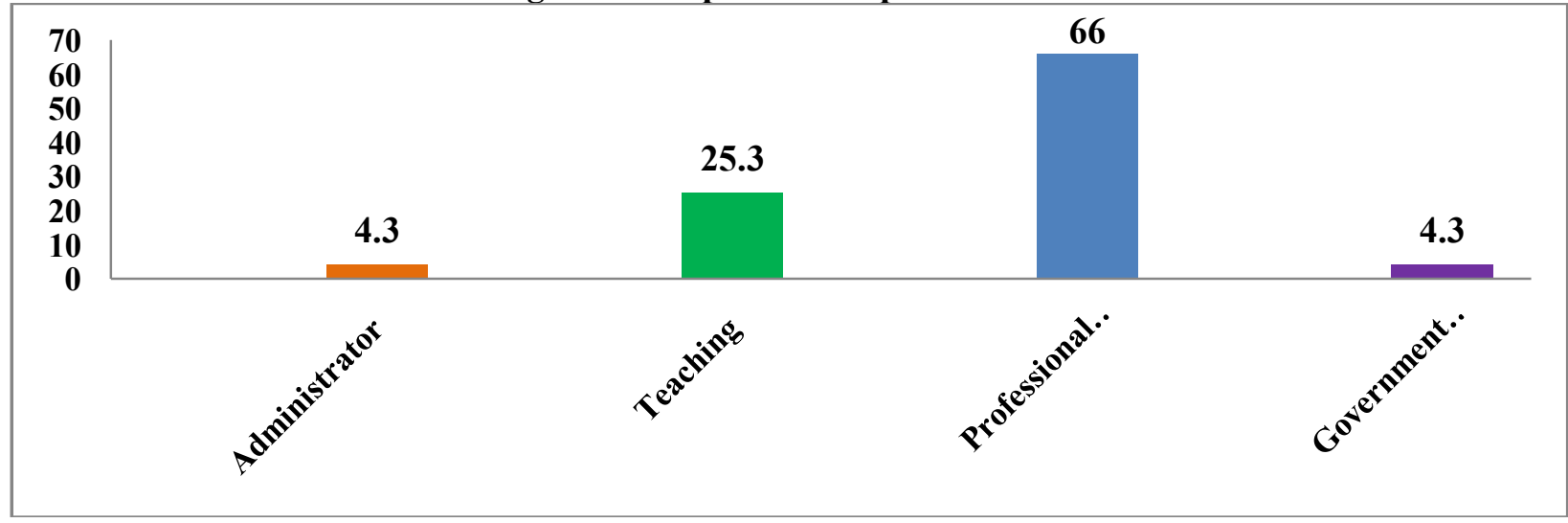


The analysis of the data on occupational aspirations indicates that two-thirds of the respondents that is 66 percent of them intended to become professional practitioner. About one fourth of the respondents that is 25 (25.3) percent of them aspire to choose teaching profession. Rest of them wantsto become administrators (4.3) percent and government personnel (4.3 percent).

It is significant to note that, professional practice is the one which preferred most by the respondents. It is still more significant to note that, the respondents studied represent scheduled caste category, though they are having reservation in government jobs and administrative positions they still prefer to be independent professional practitioners.

Further, the respondents were asked about their confidence in realizing their aspirations.

Fig 1.2: Realizing their Aspirations

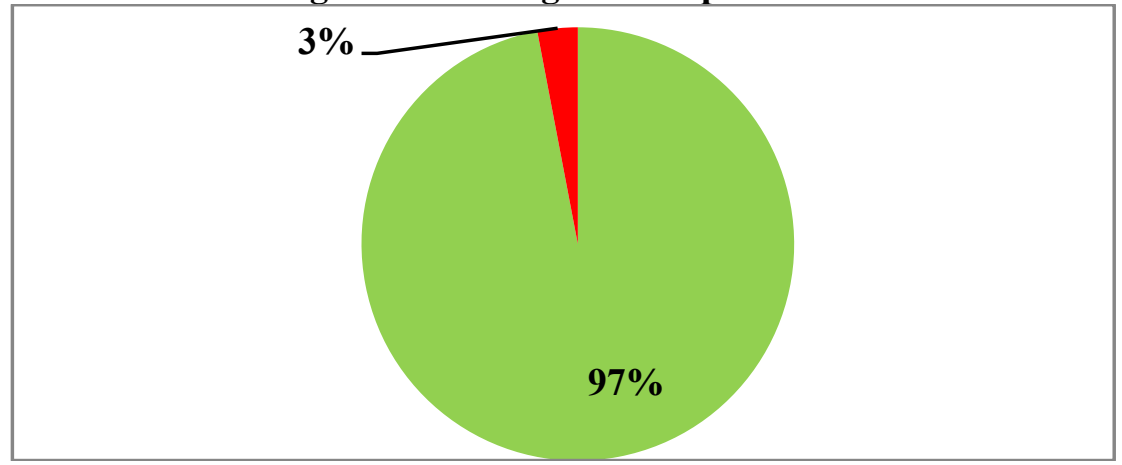

The data performing to it indicate that overwhelming majorities ( 97 percent) of the respondents have confidence in realizing their aspirations. Only about 3 percents of the respondents exhibit their negativities towards realizing their aspiration.

Correspondingly.It is significant to note that 98 (97.7) percent of the respondents believe that they have put efforts to achieve their goals. The respondents are prepared to work along with their study to achieve their aspirations.

Table 1.1: Aspiration to Become and Gender

\begin{tabular}{|l|c|c|c|}
\hline \multirow{2}{*}{ Aspiration to Become } & \multicolumn{2}{|c|}{ Gender } & \multirow{2}{*}{ Total } \\
\cline { 2 - 4 } Administrator & Male & Female & \\
\hline Teaching & $\begin{array}{c}12 \\
(8.00)\end{array}$ & $\begin{array}{c}1 \\
(0.7)\end{array}$ & 13 \\
\hline Lecturer & $\begin{array}{c}15 \\
(10.00)\end{array}$ & $\begin{array}{c}21 \\
(14.00)\end{array}$ & 36 \\
\hline Doctor & $\begin{array}{c}15 \\
(10.00)\end{array}$ & $\begin{array}{c}25 \\
(16.6)\end{array}$ & 40 \\
\hline Engineer & $\begin{array}{c}44 \\
(29.3)\end{array}$ & $\begin{array}{c}57 \\
(38.00)\end{array}$ & 101 \\
\hline Lawyer & $\begin{array}{c}43 \\
(28.7)\end{array}$ & $\begin{array}{c}36 \\
(20.00)\end{array}$ & 73 \\
\hline Police Officer & $\begin{array}{c}10 \\
(6.7)\end{array}$ & $\begin{array}{c}14 \\
(9.3)\end{array}$ & 24 \\
\hline Soldier & $\begin{array}{c}8 \\
(5.3)\end{array}$ & $\begin{array}{c}1 \\
(0.7)\end{array}$ & 9 \\
\hline Conductor & $\begin{array}{c}2 \\
(1.3)\end{array}$ & $\begin{array}{c}00 \\
(00.00)\end{array}$ & 2 \\
\hline KSRTC Driver & $\begin{array}{c}00 \\
(00.00)\end{array}$ & $\begin{array}{c}1 \\
(0.7)\end{array}$ & 1 \\
\hline $\begin{array}{c}1 \\
(0.7)\end{array}$ & $\begin{array}{c}00 \\
(00.00)\end{array}$ & 1 \\
\hline $\mathbf{2}$ & $\begin{array}{c}\mathbf{1 5 0} \\
(\mathbf{1 0 0}\end{array}$ & $\mathbf{3 0 0}$ \\
\hline
\end{tabular}


The relationship between aspiration to become and gender are positively associated at 0.01 levels.Coming to the male respondents the analysis of the data indicates that, very surprisingly only 8 percent of the male respondents prefer administrative posts, 10 percent of them aspire to become teacher, the same proportion of the male respondents aspire to become lecturers.However, nearly 30 percent of male respondents aspire to become doctors, almost same proportion that is 28.7 percent of them aspire to become Engineers.

On the other hand, significance proportion (38 percent) of the female respondents aspires to become doctors, similarly one-fifth, (20 percent) of them aspired to become engineers. Another section of females showed interest towards becoming lectures (16.6 percent) and engineers (9.3 percent).

The analysis of the data indicate that, doctor, engineer, and teachers are the most aspired jobs for male respondents. Whereas, Doctor, Engineer and teaching professions are most aspired professions for female respondents. No single female respondent aspired for soldier and driver posts. However, police officer and administrator posts are preferred by very less proportion of female respondents. It could be stated here that, these posts require most part of their life away from the family and require more physical strains and strength.The physiological conditions left with the gender very much influencing the female respondents while aspiring for the desired posts. Thus, the physiological conditions are not hurdling the male respondents in aspiring the jobs.

\section{Conclusion}

The scheduled caste students did not differ significantly from that of the other castes in their rural background and the medium of instruction. The scheduled castes by and large continue to predominative in their traditional occupation of agricultures labour. It is the urban area that they have gained most is the salaried employment sector. The scheduled castes continue their traditional occupation is the rural areas.

The study clearly focused on the attitude, self-confidence and aspiration level of the scheduled caste students in secondary education. These psychological factors play a pivotal role in the development of Childs personality and can bring fruitful results in attainingaspired goal. With this, the increasing gap between seduced castes and non-scheduled caste can be decreased and the progress of the scheduled caste members can also be brought equivalent to their counterparts know the other seeing of the society.

\section{References}

[1] Buchmann, C., and DiPrete, T.A. (2006), The Growing Female Advantage in College Completion: The Role of Family Background and Academic Achievement. American Sociological Review, 71 94), 515-541.

[2] Das, N. (1982), Some Behavior Problems of the Secondary School Students of the District of Burdwan and their Causes, Ph.D.

[3] Kleinfeld, Judith (2009), The State of American Boyhood. Gender Issues.26:113-120.

[4] Lleras, Christy (2008), "Do skills and Behaviors in High School Matter? The Contribution of Non cognitive Factors in Explaining Differences in Educational Attainment and Earning", Social Science Research 37 (3): 888-902.

[5] Chitnis, Suma (1993), School of Media and Cultural Studies Tata Institute of Social Sciences, Mumbai, India

[6] Singh, B.K. (1984), A psychological study of the patterns of personality variables of rural and urban college students of Agra region. Unpublished doctoral dissertation, Agra University. 